\title{
Zinc and childhood infections: From the laboratory to new treatment recommendations
}

\author{
Tor A. Strand and Maria Mathisen \\ Centre for International Health, University of Bergen, Norway \\ Correspondence: Tor A. Strand, Centre for International Health, University of Bergen, Armauer Hansen Building, N-5021 Bergen, Norway \\ E-mail: tor.strand@cih.uib.no Telephone: +4755974980 Telefax: +4755974979
}

\begin{abstract}
Zinc is an essential nutrient particularly important for growing children and for those who experience frequent infections. Many children in developing countries have inadequate zinc nutrition that impairs their immune system. Diarrhea and pneumonia are among the leading causes of morbidity and mortality in children of low-income countries. Zinc deficiency increases the susceptibility to these infections and administration of zinc to children with diarrhea and, possibly, pneumonia speeds up recovery. Furthermore, zinc given to otherwise healthy children also reduces the incidence of diarrhea and pneumonia. Thus, thousands of lives can be saved every year by giving zinc to prevent childhood infections or by providing zinc to children with ongoing infections. This paper gives a brief outline of the history of zinc research and reviews existing evidence from clinical trials on the prophylactic and therapeutic effect of oral zinc on childhood pneumonia and diarrhea.
\end{abstract}

\section{A BRIEF HISTORY OF ZINC NUTRITION AND RESEARCH}

More than 70 years ago scientists demonstrated that adequate zinc nutrition is important for health in mammals (1). Zinc deficiency was not, however, considered a problem in humans. In the early sixties, Prasad showed that zinc deficiency caused stunted growth and delayed sexual maturation in Iranian and Egyptian adolescents (2). In 1974 the Food and Nutrition Board of the US National Academy of Sciences declared zinc an essential nutrient and established recommended dietary allowances (RDA) for humans. Later, zinc was included in total parenteral nutrition fluids, which without a doubt have saved many lives. In 1988, Sachdev demonstrated that zinc given to Indian children with diarrhea reduced the severity of the diarrheal episode. Since then several clinical trials have confirmed the therapeutic effect of zinc given during diarrhea. The evidence is now so convincing that zinc will be included in the routine treatment for acute diarrhea in children of developing countries. Furthermore, routine zinc supplementation to apparently healthy children reduces the incidence of diarrhea, the risk of acquiring severe illness, and the risk of acute lower respiratory infections (ALRI). The available evidence will be discussed below.

\section{DIARRHEA AND ALRI IN DEVELOPING COUNTRIES}

Diarrhea and pneumonia remain important causes of morbidity and mortality in children of developing countries. Among those under 5 years of age these diseases are responsible for approximately $40 \%$ of the annual 10 million deaths. Diarrhea may be classified into three syndromes; dysentery, acute diarrhea, and persistent diarrhea. Persistent diarrhea is defined as diarrhea of a presumed infectious cause with acute onset that lasts for at least 14 days (3). Almost half of all diarrhea related deaths is attributed to this syndrome and it is now the leading cause of diarrheal deaths (3). Reduction in the proportion of diarrheal episodes that become persistent may accordingly bring down the number of diarrhea related deaths. Pneumonia and other ALRIs kill more than two million children every year. The majority of these deaths occur in the developing world $(4,5)$. The very young, the elderly, and those with conditions that interfere with immunity such as sickle-cell disease and HIV infection are particularly at high risk of severe disease (6). Pneumonia is usually treated successfully with inexpensive antibiotics. The high disease burden in many developing countries may to a large extent be ascribed to unavailability of adequate health care as well as to impaired immunity due to malnutrition (7).

\section{WHY ZINC?}

Zinc is an essential trace element important for almost all biological systems. It is required for cellular division, differentiation and growth. Organs that are dependent on continuous cell division for proper function, such as the immune system and the gut, are particularly sensitive to zinc deficiency. Inadequate zinc intake has profound effects on almost all facets of the immune system, on the mucosal integrity, and on epithelial function $(8,9)$. In humans, severe zinc deficiency is seen in those with the rare inherited disease Acrodermatitis enteropathica (AE), which is caused 
by impaired zinc absorption. Individuals with this disease have impaired growth and increased susceptibility to infections, particularly those causing diarrhea. $\mathrm{AE}$ is effectively treated with high doses of oral zinc.

Absorption of zinc depends on the amount and its solubility in the intestinal lumen. Phytic acid reduces the solubility of zinc in the gut and impairs its absorption (10-15). Phytic acid is present in legumes (e.g. beans, peas, lentils and ground nuts) and cereals (e.g. corn and sorghum), foods that are frequently consumed in many low-income countries. Meat and other animal products are generally rich in zinc, contain amino acids that promote zinc absorption, and are accordingly good sources of bioavailable zinc (10). Furthermore, the demand for zinc is high in individuals with a rapid growth rate, i.e. fetuses, children and adolescents (8). Zinc is excreted in the stools and substantial amounts of zinc is lost during diarrhea (16). Thus, zinc nutriture is likely to be suboptimal in many children of developing countries and contributes to their impaired growth, an increased susceptibility to infections and possibly to their high mortality.

\section{ASSESSMENT OF ZINC STATUS}

Plasma zinc and serum zinc are currently the most commonly used indicators of zinc status in humans. However, these markers are of limited value because less than $1 \%$ of the total body zinc circulates in the plasma and because plasma zinc concentration is affected by several conditions such as hypoalbuminemia, hemoconcentration, and the acute phase response (17). In fact, the reduction in plasma zinc seems to reflect the severity of the infection $(18,19)$ and may be observed early during the illness, even before signs of infection, such as fever, appear (20). Due to lack of adequate biomarkers, zinc supplementation trials are essential in understanding the epidemiology of zinc deficiency and to explore a causal effect between zinc deficiency and increased morbidity.

\section{Prevention OF DIARRHEA WITH ZINC}

Clinical trials in children, usually from relatively marginalized strata of developing countries, have shown that routine zinc supplementation reduces the incidence and prevalence of diarrhea (Table 1, Figure 1) (21-28). A pooled analysis of zinc supplementation trials used published and unpublished data from 10 developing countries to assess the efficacy of daily zinc administration on diarrheal morbidity (29). This analysis concluded that zinc-supplemented children had an $18 \%(95 \%$ CI 7\%, 28\%) lower incidence rate and a $25 \%$ (95\% CI 12\%, 37\%) lower prevalence of diarrhea compared to children that were not given zinc. This publication also included a pooled analysis from three trials that used short-term zinc supplementation. In these studies the children were supplemented with 2-4 RDA (30) zinc for two weeks and then observed for another 2 to 3 months. The combined pooled effect of these short courses of zinc supplementation on the prevalence (odds ratio [OR] $0.66,95 \%$ CI $0.52,0.83$ ) and incidence rate (OR $0.89,95 \%$ CI $0.62,1.28$ ) of diarrhea was similar to what was seen in the trials supplementing children with zinc throughout the observation period. After this pooled analysis was published, large studies have confirmed this reduction in diarrheal morbidity both in routine $(21,22)$ and in short term zinc supplementation trials. Bhandari and coworkers conducted the largest of these trials, which included 2,500 Indian children (22). They showed that four months of routine zinc supplementation to children aged 6 to 30 months reduced the incidence of severe and prolonged diarrhea. Furthermore, in a recent trial the investigators showed that even only a weekly dose substantially reduced the incidence of diarrhea (31). This study also demonstrated a substantial effect of zinc on pneumonia (se below).

\section{TREATMENT OF DIARRHEA WITH ZINC}

Sachdev and coworkers were the first to assess the therapeutic effects of zinc on diarrhea (32). In a study on acute diarrhea they found that children who were given $40 \mathrm{mg}$ of elemental zinc daily had shorter duration of diarrhea and lower stool frequency than the controls. Following this publication, several trials on zinc administration during acute and persistent diarrhea have been conducted and the results from these trials have been summarized in two pooled analyses (33). The analysis that included children with acute diarrhea demonstrated that there was an overall and statistically significant $15 \%$ reduction of the duration in children receiving zinc (Hazard ratio 0.85, 95\% CI $0.76,0.95)$. In the trials that enrolled children with persistent diarrhea, therapeutic zinc reduced the time till recovery of diarrhea by $24 \%$ (Hazard ratio 0.76 , $95 \%$ CI $0.63,0.91)$ and the risk of treatment failure or death (OR 0.61, 95\% CI 0.26, 1.46).

Table 1. Effects of zinc on preventing childhood diarrhea and pneumonia.

\begin{tabular}{llccc}
\hline $\begin{array}{l}\text { Author, year } \\
\text { (reference no) }\end{array}$ & Country & $\mathrm{n}$ & Diarrhea $^{1}$ & ALRI $^{1}$ \\
\hline Ninh, 1996 (23) & Vietnam & 146 & $44^{2}$ & $44^{2}$ \\
Rosado, 1997 (49) & Mexico & 219 & 37 & \\
Ruel, 1997 (25) & Guatemala & 89 & $18^{2}$ & \\
Sazawal, 1998 (40) & India & 609 & 8 & $43^{2}$ \\
Penny, 1999 (41) & Peru & 173 & $12^{2}$ & 15 \\
Shankar, 2000 (50) & Papua New Guinea & 274 & 12 & \\
Umeta, 2000 (51) & Ethiopia & 200 & $55^{2}$ & \\
Muller, 2001 (21) & Burkina Faso & 685 & $16^{2}$ & 57 \\
Bhandari, 2002 (43) & India & 2482 & & $26^{2}$ \\
Bhandari, 2002 (22) & India & 2500 & $12^{2}$ & \\
Brooks, 2005 (31) & Bangladesh & 1665 & $6^{2}$ & $17^{2}$ \\
\hline
\end{tabular}

${ }^{1} \%$ lower incidence or risk of disease among those given zinc.

${ }^{2}$ Statistically significant, i.e. $p<0.05$ 


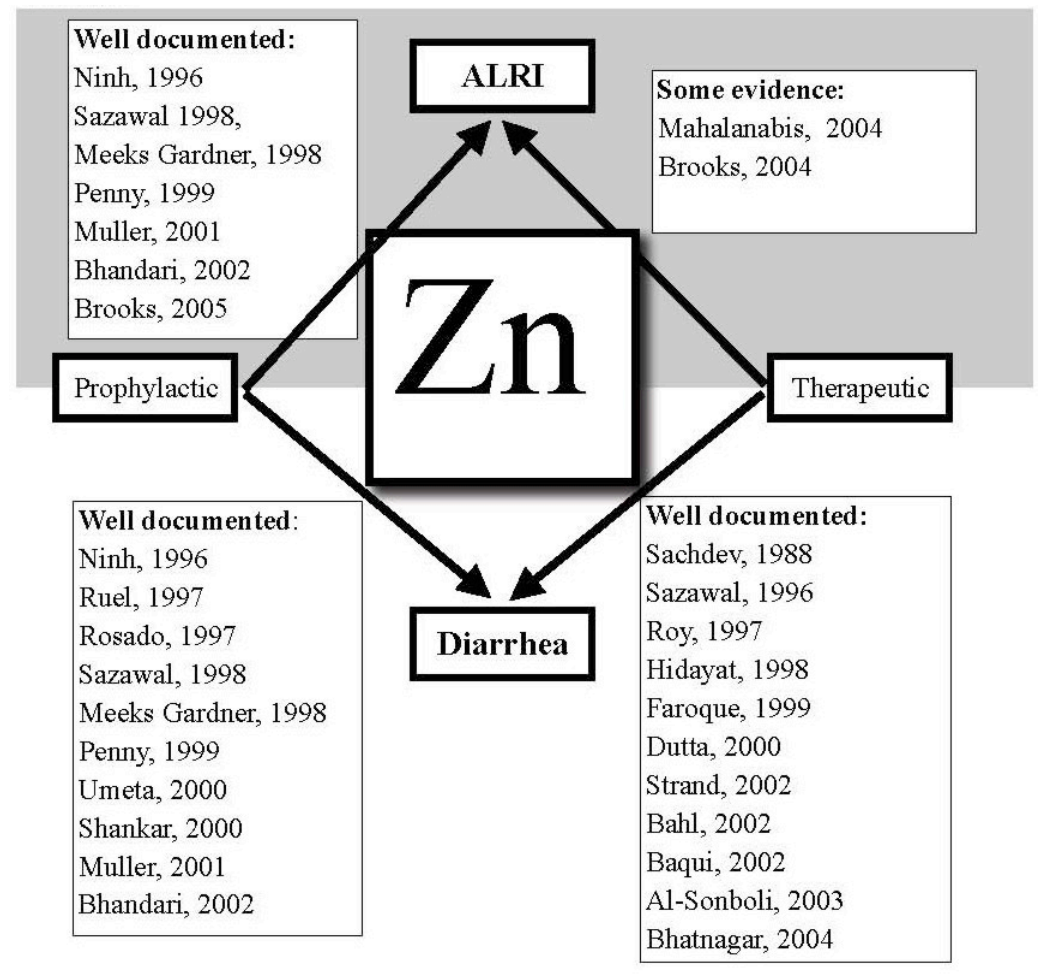

ALRI: Acute lower respiratory infection

Figure 1. Existing evidence for the effect of zinc (prophylactic and therapeutic) on the two most common causes of death due to infections in children of low-income countries.

Table 2. Studies evaluating therapeutic effects of zinc supplementation in the treatment of acute diarrhea.

\begin{tabular}{llrccc}
\hline Author, year (reference no) & Country & \multicolumn{1}{c}{ D } & Dose * & Difference $\dagger(95 \%$ CI) & Odds ratio episode $>7$ days $\dagger \dagger$ \\
\hline Sachdev, 1988 (52) & India & 50 & $40 \mathrm{mg}$ & $-0.4(-1.4,0.6)$ & \\
Faruque, 1999 (53) & Bangladesh & 681 & $14.2 / 40 \mathrm{mg}$ & $-1.0(-1.8,-0.2)$ & \\
Dutta, 2000 (54) & India & 80 & $40 \mathrm{mg}$ & $-1.4(-1.6,-1.1)$ & \\
Al Soboni, 2001 (37) & Brazil & 74 & $22.5 / 45 \mathrm{mg}$ & $-1.3(-1.9,-0.6)$ & \\
& & & & Relative Hazards $(95 \% \mathrm{CI})$ & \\
Sazawal, 1996(24) & India & 937 & $20 \mathrm{mg}$ & $0.79(0.69,0.90)$ & $0.85(0.60,1.19)$ \\
Roy, 1997 (55) & Bangladesh & 111 & $20 \mathrm{mg}$ & $0.85(0.57,1.28)$ & $0.77(0.33,1.79)$ \\
Hidayat, 1998 (56) & Indonesia & 1398 & $4.5 \mathrm{mg} / \mathrm{kg}$ & $0.92(0.83,1.02)$ & $0.72(0.48,1.07)$ \\
Bahl, 2002 (35) & India & 805 & $15 / 30 \mathrm{mg}$ & $0.89(0.80,0.99)$ & $0.61(0.33,1.12)$ \\
Strand, 2002 (36) & Nepal & 1792 & $15 / 30 \mathrm{mg}$ & $0.79(0.68,0.93)$ & $0.57(0.38,0.86) * *$ \\
Baqui, 2002 (34) & Bangladesh & 1252 & $20 \mathrm{mg}$ & $0.77(0.65,0.90)$ & \\
Bhatnagar, 2004 (57) & India & 168 & $15 / 30 \mathrm{mg}$ & $0.77(0.59,0.99)$ & \\
\hline
\end{tabular}

* elemental zinc

$\dagger$ mean difference in days

** relative risk

$\dagger \dagger$ odds of having an episode in those who received zinc compared to the placebo group

After these pooled analyses were published, more studies on the therapeutic use of zinc in diarrhea have been completed (34-37). The results of these studies were presented in a WHO meeting in New Delhi in 2001 and the report from this meeting (38) concludes: "Based on the results of this review, it is concluded that there is now enough evidence demonstrating the efficacy of zinc supplementation on the clinical course of diarrhoea, with regard to the severity and duration of the episode".

The results from a trial we undertook in 1,792 Nepalese children aged 6 to 35 months with acute diarrhea were included in this report (36). In this trial the risk of persistent diarrhea was reduced from 5.2\% 
to $2.7 \%$, corresponding to an absolute risk reduction of $2.5 \%(95 \%$ CI $0.2 \%, 5 \%)$ in those who received zinc (39). An almost 50\% reduction in the risk of persistent diarrhea is promising and this finding is supported by a cluster-randomized trial in Bangladeshi children (34). In this trial 40 non-injury fatalities were reported and the risk of such deaths was $51 \%$ (95\% CI 5\%, 75\%) lower among children belonging to clusters that were offered zinc as adjunct therapy for acute diarrhea.

\section{PreVention OF ACUTE LOWER RESPIRA- TORY INFECTIONS (ALRI) WITH ZINC}

The above-mentioned pooled analysis of preventive zinc supplementation trials also included data for ALRI from four trials (29) (Table 1, Figure 1). This analysis of data from India (40), Vietnam (23), Peru (41), and Jamaica (42) showed that routine zinc supplementation reduced the odds of getting pneumonia by $41 \%$ (95\% CI $17 \%, 69 \%)$. Later, Bhandari and coworkers confirmed this reduction in the incidence of clinical pneumonia in 2,500 Indian children that were given zinc on a daily basis (43). Zinc appeared to confer largest protection to those with severe illness. This finding was supported by the recently published trial where 1665 Bangladeshi children were given $70 \mathrm{mg}$ zinc or placebo weekly (31). In this study only infants between 2 and 12 months of age were included. The incidence of pneumonia was $17 \%$ lower (95\% CI: 5\%, 27\%) among those given zinc compared to the placebo recipients. Even more important, the study reported a strong effect of zinc on mortality; 10 of the children in the placebo group died, whereas only 2 of the children in the zinc group died during the observation period. This corresponds to an $85 \%$ reduction in mortality. Respiratory infections was the main cause of death.

\section{TREATMENT OF LOWER RESPIRATORY INFECTIONS WITH ZINC}

There is limited information on zinc as adjunct therapy for ALRI and pneumonia (Figure 1). One published trial that included children with measles related pneumonia showed no effect (44). However, two other studies showed an impact of zinc on the duration of the illness, in one of which only an effect in boys was observed (45). The largest and the most recent of these two trials demonstrated a $30 \%$ reduction in the duration of the episode (RH $0.70,95 \%$ CI $0.51,0.98)$ (46) with no gender differences. However, the therapeutic effect of zinc administration on pneumonia might be more difficult to measure compared to the effect of zinc on diarrhea. This is partly because the study participants also have to be offered effective antibiotics that dilute the possible effect zinc. The three trials mentioned above were relatively small and totally they included only 508 children. More and larger clinical trials should accordingly be undertaken.

\section{MORTALITY AND ZINC}

In a trial on low birth weight babies in North India, placebo or $5 \mathrm{mg}$ elemental zinc as zinc sulfate was given daily between 30 and 284 days of age. There were five fatalities among the zinc supplemented and 15 among the placebo recipients. The relative risk of dying between those in the zinc group and those in the placebo group was accordingly 0.32 (95\% CI 0.12 , $0.89)$. The results from this trial, the trial that demonstrated a reduced death risk in children belonging to clusters that received zinc as adjunct therapy for acute diarrhea (34), and the trial that showed an $85 \%$ reduction in infant mortality of children given weekly zinc (31) are promising. Thus, zinc administration can reduce childhood mortality - probably through the reduction in severe episodes of pneumonia and diarrhea.

\section{CONCLUSION}

Seventy years of zinc research have resulted in new treatment recommendations for acute diarrhea. Zinc might also be beneficial when given during pneumonia, and children that are given zinc regularly have a reduced burden of diarrhea and pneumonia, both important causes of childhood death. Around half of the world's population and $95 \%$ of the South Asian population are at risk of low zinc intake (47). Zinc administration reduces the burden of diarrhea and pneumonia, and according to a recent publication in the Lancet by Jones and coworkers, therapeutic and prophylactic zinc administration have the potential of reducing almost $10 \%$ of the under 5 mortality, mainly through a reduction of the incidence and severity of diarrhea and pneumonia (48).

There is a need to develop and implement strategies to improve zinc nutriture. The delayed effect of short-term zinc administration is promising. Short courses of zinc administration in order to reduce the burden of zinc deficiency is attractive compared to long-term administration that can interfere with current breastfeeding recommendations. This downstream effect of zinc needs, however, to be explored further. The doses that have been used for the treatment of pneumonia and to induce a downstream effect are similar to those recommended to treat diarrhea. Thus, when zinc is available for the treatment of acute diarrhea, other indications for its use should be easy to implement.

\section{ACKNOWLEDGEMENT}

This paper was supported by grants from the Norwegian Research Council. 


\section{REFERENCES}

1. Todd WR, Elvehjem CA, Hart EB. Zinc in the nutrition of the rat. Am J Physiol 1934; 107: 146-56.

2. Prasad AS, Farid Z, Sandstead HH, Miale AJ, Schulert AR. Zinc metabolism in patients with the syndrome of iron deficiency anemia, hepatosplenomegaly, dwarfism, and hypogonadism. J Lab Clin Med 1963; 61 (4): $537-49$.

3. Black RE. Persistent diarrhea in children of developing countries. Pediatr Infect Dis $J$ 1993; 12 (9): 751-61; discussion 762-4.

4. Leowski J. Mortality from acute respiratory infections in children under 5 years of age: global estimates. World Health Stat Q 1986; 39 (2): 138-44.

5. World Development report 1993. New York: Oxford University press, 1993.

6. Obaro SK, Monteil MA, Henderson DC. The pneumococcal problem. BMJ 1996; 312 (7045): 1521-5.

7. Bang AT, Bang RA, Tale O, Sontakke P, Solanki J, Wargantiwar R, et al. Reduction in pneumonia mortality and total childhood mortality by means of community-based intervention trial in Gadchiroli, India. Lancet 1990; 336 (8709): 201-6.

8. Walsh CT, Sandstead HH, Prasad AS, Newberne PM, Fraker PJ. Zinc: health effects and research priorities for the 1990s. Environ Health Perspect 1994; 2: 5-46.

9. Koo SI, Turk DE. Effect of zinc deficiency on the ultrastructure of the pancreatic acinar cell and intestinal epithelium in the rat. $J$ Nutr 1977; 107 (5): 896-908.

10. Lonnerdal B. Dietary factors influencing zinc absorption. J Nutr 2000; 130 (Suppl 5): 1378S-83S.

11. Hunt JR, Matthys LA, Johnson LK. Zinc absorption, mineral balance, and blood lipids in women consuming controlled lactoovovegetarian and omnivorous diets for $8 \mathrm{wk}$. Am J Clin Nutr 1998; 67 (3): 421-30.

12. Sandstrom B, Almgren A, Kivisto B, Cederblad A. Zinc absorption in humans from meals based on rye, barley, oatmeal, triticale and whole wheat. J Nutr 1987; 117 (11): 1898-902.

13. Sandstrom B, Sandberg AS. Inhibitory effects of isolated inositol phosphates on zinc absorption in humans. $J$ Trace Elem Electrolytes Health Dis 1992; 6 (2): 99-103.

14. Ellis R, Kelsay JL, Reynolds RD, Morris ER, Moser PB, Frazier CW. Phytate: zinc and phytate X calcium: zinc millimolar ratios in self-selected diets of Americans, Asian Indians, and Nepalese. J Am Diet Assoc 1987; 87 (8): 1043-7.

15. Forbes RM, Erdman JW, Jr. Bioavailability of trace mineral elements. Annu Rev Nutr 1983; 3: 213-21.

16. Ruz M, Solomons NW. Fecal zinc of endogenous zinc during oral rehydration therapy for acute diarrhoea. $J$ Trace Elem Exp Med 1995; 7: 89-100.

17. Strand TA, Adhikari RK, Chandyo RK, Sharma PR, Sommerfelt H. Predictors of plasma zinc concentrations in children with acute diarrhea. Am J Clin Nutr 2004; 79 (3): 451-6.

18. Mwangi SM, McOdimba F, Logan-Henfrey L. The effect of Trypanosoma brucei infection on rabbit plasma iron and zinc concentrations. Acta Trop 1995; 59 (4): 283-91.

19. Pekarek RS, Beisel WR. Effect of endotoxin on serum zinc concentrations in the rat. Appl Microbiol 1969; 18 (3): 482-4.

20. Beisel WR. Zinc metabolism in infection. In: Prasad AS, ed. Zinc metabolism: current aspects in health and disease. New York: Alan R Liss, 1977: 973-7.

21. Muller O, Becher H, van Zweeden AB, Ye Y, Diallo DA, Konate AT, et al. Effect of zinc supplementation on malaria and other causes of morbidity in west African children: randomised double blind placebo controlled trial. BMJ 2001; 322 (7302): 1567.

22. Bhandari N, Bahl R, Taneja S, Strand TA, Molbak K, Ulvik RJ, et al. Substantial reduction in severe diarrheal morbidity by daily zinc supplementation in young north Indian children. Pediatrics 2002; 109 (6): e86.

23. Ninh NX, Thissen JP, Collette L, Gerard G, Khoi HH, Ketelslegers JM. Zinc supplementation increases growth and circulating insulin-like growth factor I (IGF-I) in growth-retarded Vietnamese children. Am J Clin Nutr 1996; 63 (4): 514-9.

24. Sazawal S, Black RE, Bhan MK, Jalla S, Sinha A, Bhandari N. Efficacy of zinc supplementation in reducing the incidence and prevalence of acute diarrhea - a community-based, double-blind, controlled trial. Am J Clin Nutr 1997; 66 (2): 413-8.

25. Ruel MT, Rivera JA, Santizo MC, Lonnerdal B, Brown KH. Impact of zinc supplementation on morbidity from diarrhea and respiratory infections among rural Guatemalan children. Pediatrics 1997; 99 (6): 808-13.

26. Rosado JL, Lopez P, Munoz E, Martinez H, Allen LH. Zinc supplementation reduced morbidity, but neither zinc nor iron supplementation affected growth or body composition of Mexican preschoolers [see comments]. Am J Clin Nutr 1997; 65 (1): 13-9.

27. Lira PI, Ashworth A, Morris SS. Effect of zinc supplementation on the morbidity, immune function, and growth of low-birth-weight, full-term infants in northeast Brazil. Am J Clin Nutr 1998; 68 (2 Suppl): 418S$424 \mathrm{~S}$. 
28. Umeta M, West CE, Haidar J, Deurenberg P, Hautvast JG. Zinc supplementation and stunted infants in Ethiopia: a randomised controlled trial [see comments]. Lancet 2000; 355 (9220): 2021-6.

29. The Zinc Investigators' Collaborative Group. Prevention of diarrhea and pneumonia by zinc supplementation in children in developing countries: pooled analysis of randomized controlled trials. J Pediatr 1999; 135 (6): 689-97.

30. National Academy of Sciences. Recommended Daily Allowances, 10th edn. Washington, DC: National Academy Press, 1989.

31. Brooks WA, Santosham M, Naheed A, Goswami D, Wahed MA, Diener-West M, et al. Effect of weekly zinc supplements on incidence of pneumonia and diarrhoea in children younger than 2 years in an urban, lowincome population in Bangladesh: randomised controlled trial. Lancet 2005; 366 (9490): 999-1004.

32. Sachdev HP, Mittal NK, Mittal SK, Yadav HS. A controlled trial on utility of oral zinc supplementation in acute dehydrating diarrhea in infants. J Pediatr Gastroenterol Nutr 1988; 7 (6): 877-81.

33. The Zinc Investigators' Collaborative Group. Therapeutic effects of oral zinc in acute and persistent diarrhea in children in developing countries: pooled analysis of randomized controlled trials. Am J Clin Nutr 2000; 72 (6): 1516-22.

34. Baqui AH, Black RE, El Arifeen S, Yunus M, Chakraborty J, Ahmed S, et al. Effect of zinc supplementation started during diarrhoea on morbidity and mortality in Bangladeshi children: community randomised trial. BMJ 2002; 325 (7372): 1059.

35. Bahl R, Bhandari N, Saksena M, Strand T, Kumar GT, Bhan MK, et al. Efficacy of zinc-fortified oral rehydration solution in 6- to 35-month-old children with acute diarrhea. J Pediatr 2002; 141 (5): 677-82.

36. Strand TA, Chandyo RK, Bahl R, Sharma PR, Adhikari RK, Bhandari N, et al. Effectiveness and efficacy of zinc for the treatment of acute diarrhea in young children. Pediatrics 2002; 109 (5): 898-903.

37. Al-Sonboli N, Gurgel RQ, Shenkin A, Hart CA, Cuevas LE. Zinc supplementation in Brazilian children with acute diarrhoea. Ann Trop Paediatr 2003; 23 (1): 3-8.

38. Fontaine O. Effect of zinc supplementation on clinical course of acute diarrhoea. J Health Popul Nutr 2001; 19 (4): 339-46.

39. Strand TA. Zinc and childhood infections studies in mice and men. PhD thesis, University of Bergen, 2003.

40. Sazawal S, Black RE, Jalla S, Mazumdar S, Sinha A, Bhan MK. Zinc supplementation reduces the incidence of acute lower respiratory infections in infants and preschool children: a double-blind, controlled trial. Pediatrics 1998; 102 (1 Pt 1): 1-5.

41. Penny ME, Peerson JM, Marin RM, Duran A, Lanata CF, Lonnerdal B, et al. Randomized, community-based trial of the effect of zinc supplementation, with and without other micronutrients, on the duration of persistent childhood diarrhea in Lima, Peru. J Pediatr 1999; 135 (2 Pt 1): 208-17.

42. Meeks Gardner J, Witter MM, Ramdath DD. Zinc supplementation: effects on the growth and morbidity of undernourished Jamaican children. Eur J Clin Nutr 1998; 52 (1): 34-9.

43. Bhandari N, Bahl R, Taneja S, Strand T, Molbak K, Ulvik RJ, et al. Effect of routine zinc supplementation on pneumonia in children aged 6 months to 3 years: randomised controlled trial in an urban slum. BMJ 2002; 324 (7350): 1358.

44. Mahalanabis D, Chowdhury A, Jana S, Bhattacharya MK, Chakrabarti MK, Wahed MA, et al. Zinc supplementation as adjunct therapy in children with measles accompanied by pneumonia: a double-blind, randomized controlled trial. Am J Clin Nutr 2002; 76 (3): 604-7.

45. Mahalanabis D, Lahiri D, Paul D, Gupta S, Gupta A, Wahed MA, et al. Randomized, double-blind, placebocontrolled clinical trial of the efficacy of treatment with zinc or vitamin A in infants and young children with severe acute lower respiratory infection. Am J Clin Nutr 2004; 79: 430-436.

46. Brooks WA, Yunus M, Santosham M, Wahed MA, Nahar K, Yeasmin S, et al. Zinc for severe pneumonia in very young children: double-blind placebo-controlled trial. Lancet 2004; 363 (9422): 1683-8.

47. Brown KH, Wuheler SE. Zinc and human health: results of recent trials and implications for program interventions and research. In: Centre IDR, ed. The Micronutrient intiative. Ottawa, 2000: 1-68.

48. Jones G, Steketee RW, Black RE, Bhutta ZA, Morris SS. How many child deaths can we prevent this year? Lancet 2003; 362 (9377): 65-71.

49. Rosado JL, Lopez P, Munoz E, Martinez H, Allen LH. Zinc supplementation reduced morbidity, but neither zinc nor iron supplementation affected growth or body composition of Mexican preschoolers. Am J Clin Nutr 1997; 65 (1): 13-9.

50. Shankar AH. Nutritional modulation of malaria morbidity and mortality. J Infect Dis 2000; 182 (Suppl 1): S37-S53.

51. Umeta M, West CE, Haidar J, Deurenberg P, Hautvast JG. Zinc supplementation and stunted infants in Ethiopia: a randomised controlled trial. Lancet 2000; 355 (9220): 2021-6.

52. Sachdev HP, Mittal NK, Mittal SK, Yadav HS. A controlled trial on utility of oral zinc supplementation in acute dehydrating diarrhea in infants. J Pediatr Gastroenterol Nutr 1988; 7 (6): 877-81. 
53. Faruque ASG MD, Haque SS, Fuch GJ, Habte D. Double-blind, randomized,controlled trial of zinc or vitamin A supplementation in young children with acute diarrhea. Acta Paediatr 1999; 88: 154-60.

54. Dutta P, Mitra U, Datta A, Niyogi SK, Dutta S, Manna B, et al. Impact of zinc supplementation in malnourished children with acute watery diarrhoea. J Trop Pediatr 2000; 46 (5): 259-63.

55. Roy SK, Tomkins AM, Akramuzzaman SM, Behrens RH, Haider R, Mahalanabis D, et al. Randomised controlled trial of zinc supplementation in malnourished Bangladeshi children with acute diarrhoea. Arch Dis Child 1997; 77 (3): 196-200.

56. Hidayat A, Achadi A, Sunoto, Soedarno SP. The effect of zinc supplementation in children under three years of age with acute diarrhea in Indonesia. Med J Indonesia 1998; 7: 237-41.

57. Bhatnagar S, Bahl R, Sharma PK, Kumar GT, Saxena SK, Bhan MK. Zinc with oral rehydration therapy reduces stool output and duration of diarrhea in hospitalized children: a randomized controlled trial. J Pediatr Gastroenterol Nutr 2004; 38 (1): 34-40. 